MINERALOGIA, 43, No 1-2: 129-135 (2012)

DOI: 10.2478/V10002-012-0004-4

www.Mineralogia.pl

MineRALOGICAL SocietY of Poland

Polskie TOWARZYSTWO MINERALOGICZNE

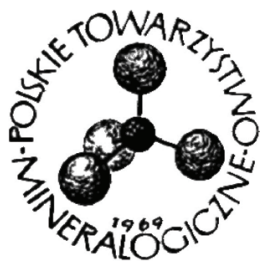

Original paper

\title{
Synthesis and solubility of brompyromorphite $\mathrm{Pb}_{5}\left(\mathrm{PO}_{4}\right)_{3} \mathrm{Br}$
}

\author{
Urszula JANICKA, Tomasz BAJDA*, Maciej MANECKI \\ AGH University of Science and Technology, Faculty of Geology, Geophysics and Environment Protection, \\ al. Mickiewicza 30,30-059 Krakow,Poland,e-mail: bajda@geol.agh.edu.pl \\ * Corresponding author
}

Received: February 27, 2012

Received in revised form: November 6, 2012

Accepted: November 8, 2012

Available online: November 15, 2012

\begin{abstract}
The bromide analogue of pyromorphite $\mathrm{Pb}_{5}\left(\mathrm{PO}_{4}\right)_{3} \mathrm{Br}$ was synthesized and characterized by $\mathrm{X}$-ray diffraction, infrared spectroscopy and scanning electron microscopy. The solubility of the brompyromorphite was measured at $25^{\circ} \mathrm{C}$ and $\mathrm{pH}$ values of $2.0,2.6$ and 3.2. For the $3 \mathrm{pH}$ measurements, the average solubility product, $\log \mathrm{K}_{\mathrm{SP}}$, for the reaction $\mathrm{Pb}_{5}\left(\mathrm{PO}_{4}\right)_{3} \mathrm{Br} \Leftrightarrow 5 \mathrm{~Pb}^{2+}+3 \mathrm{PO}_{4}{ }^{3-}+\mathrm{Br}^{-}$at $25^{\circ} \mathrm{C}$ is $-77.38 \pm 0.70$. The free energy of formation, $\Delta \mathrm{G}_{\mathrm{f}, 298}^{\circ}$, calculated from this measured solubility product is $-3724.7 \pm 4.3 \mathrm{~kJ} \mathrm{~mol}^{-1}$. These results confirm that brompyromorphite is more soluble than pyromorphite.
\end{abstract}

Key-words: lead, phosphate, apatite, dissolution, brompyromorphite, solubility product

\section{Introduction}

Because of numerous possible substitutions, over 40 different minerals belong to the apatite supergroup (Pan, Fleet 2002; Pasero et al. 2010). This fact has inspired many studies of synthetic solid solutions based on the apatite structure. The apatite group of minerals includes the lead-phosphates pyromorphite $\mathrm{Pb}_{5}\left(\mathrm{PO}_{4}\right)_{3} \mathrm{Cl}$, hydroxylpyromorphite $\mathrm{Pb}_{5}\left(\mathrm{PO}_{4}\right)_{3} \mathrm{OH}$, fluorpyromorphite $\mathrm{Pb}_{5}\left(\mathrm{PO}_{4}\right)_{3} \mathrm{~F}$, brompyromorphite $\mathrm{Pb}_{5}\left(\mathrm{PO}_{4}\right)_{3} \mathrm{Br}$, and various arsenate and vanadate analogs (Pan, Fleet 2002; Pasero et al. 2010). Pyromorphite is one of the most stable lead compounds in earth-surface environments and its precipitation is one of the effective methods used to remove lead ions from contaminated soils and solutions (Cotter-Howells 1996; Shevade et al. 2001; Krik et al. 2002). Other pyromorphite variants 
such as brompyromorphite (BrPY) are less well known (Nriagu 1973). Its properties are of interest, particularly as $\mathrm{Pb}_{5}\left(\mathrm{PO}_{4}\right)_{3} \mathrm{Br}$ can control the concentration of lead and phosphates through $\mathrm{Pb}$ and $\mathrm{PO}_{4}$ sorption on surfactant-modified (amine hexadecyltrimethylammonium bromide) smectite (Figuła, Bajda 2010). The aims of this study are the characterization of the synthetic bromide analogue of pyromorphite and the determination of its solubility product based on the results of dissolution experiments.

\section{Material and methods}

\subsection{Synthesis of brompyromorphite $\mathrm{Pb}_{5}\left(\mathrm{PO}_{4}\right)_{3} \mathrm{Br}$}

To synthesize $10 \mathrm{~g}$ of brompyromorphite, $11.8 \mathrm{~g}$ of $\mathrm{Pb}\left(\mathrm{NO}_{3}\right)_{2}, 3.7 \mathrm{~g}$ of $\mathrm{K}_{2} \mathrm{HPO}_{4}$ and $0.85 \mathrm{~g}$ of $\mathrm{KBr}$ were individually dissolved in $300 \mathrm{~mL}$ of redistilled water at $25^{\circ} \mathrm{C}$. With the use of a peristaltic pump, these three solutions were gradually and simultaneously mixed into a $3 \mathrm{~L}$ beaker filled with $1.5 \mathrm{~L}$ of continuously-stirred redistilled water. A white precipitate appeared immediately upon mixing. After the $\mathrm{Pb}, \mathrm{PO}_{4}$ and $\mathrm{Br}$ solutions were exhausted, the suspension was left to age for 28 days. It was then decanted, filtered and then washed first with redistilled water and later with acetone. The precipitate was dried at $110^{\circ} \mathrm{C}$ for $12 \mathrm{~h}$.

\subsection{Precipitate and solution characterization}

The precipitate was analyzed using an X-ray powder diffractometer (Philips PW 3020 X'Pert-APD Diffractometer system with graphite monochromator, Philips, Netherlands) using $\mathrm{CuK} \alpha$ radiation, step scan mode with a step size of $0.02^{\circ} 2 \Theta$ and a rate of $1 \mathrm{~s}$ per step. Fourier-transform infrared (FTIR) spectra were recorded on a Bio-Rad FTS-60 spectrometer (BIO-RAD, USA) from 4000 to $400 \mathrm{~cm}^{-1}$. Scanning electron microscopy (SEM) was performed using a FEI QUANTA 200 FEG microscope (FEI, USA) with Energy Dispersive Spectrometer (EDS) on carbon-coated samples. From the supernatant solutions, total $\mathrm{Pb}$ concentration was determined by atomic absorption spectroscopy (AAS; Philips PU-9100x, Philips, United Kingdom). $\mathrm{PO}_{4}$ concentrations were determined colourimetrically by the molybdenum blue method (Lenoble et al. 2003) using a Hitachi 1600 spectrophotometer (Hitachi, Japan) at $870 \mathrm{~nm}$ wavelength.

\subsection{Dissolution experiments}

Dissolution experiments were conducted at $25^{\circ} \mathrm{C}$ with initial $\mathrm{pH}$ values of $2.0,2.6$ and 3.2. For each, an $250 \mathrm{mg}$ aliquot of synthetic $\mathrm{Pb}_{5}\left(\mathrm{PO}_{4}\right)_{3} \mathrm{Br}$ was added to $250 \mathrm{~mL}$ of $0.05 \mathrm{M}$ $\mathrm{KNO}_{3}$ and the $\mathrm{pH}$ adjusted to the desired value using $0.1 \mathrm{M} \mathrm{HNO}_{3}$. All experiments were conducted in triplicate in unbuffered suspensions. In each case, the $\mathrm{pH}$ was allowed to drift freely after the initial value was set. To determine that equilibration had been reached, samples of the reaction solutions were taken after $2 \mathrm{~h}$ and after 1, 2, 4, 7, 14, 21, 28, 42, 56, and 93 days. The bottles containing the suspensions were shaken twice a week and always after sampling. For each sample, the solids were allowed to settle before $7 \mathrm{~mL}$ of the supernatant was withdrawn, without refilling with the solution afterwards. The samples 
were analyzed for $\mathrm{pH}$ (combined glass electrode), $\mathrm{Pb}_{\text {tot }}$ (AAS) and $\mathrm{P}(\mathrm{V})_{\text {tot }}$ (molybdene blue method; Lenoble et al. 2003) while [Br] was calculated from the stoichiometry of the dissolved solids. Calculations of solubility products were performed with the aid of the computer program PHREEQC with modified MINTEQ.v4 thermodynamic database (Allison et al. 1991). The activities of ionic species were calculated from measured concentrations of elements by applying the Davies equation or the extended Debye-Huckel equation.

\section{Results and discussion}

\subsection{X-Ray diffraction (XRD)}

The white precipitate produced in the synthesis was identified as the bromide analogue of pyromorphite $\mathrm{Pb}_{5}\left(\mathrm{PO}_{4}\right)_{3} \mathrm{Br}$ by comparing peak positions with those of Br-pyromorphite reported in Joint Committee on Powder Diffraction Standards (JCPDS) cards 32-0533 and 06-0365. All peaks produced by the precipitate were identified as brompyromorphite peaks (Fig. 1). Calculated unit cell parameters are: $a=10.074(1) \AA$ and $c=7.373(1) \AA$. These values agree well with the values of $a=10.145 \AA$ and $c=7.347 \AA$ reported for synthetic lead bromide phosphate (JCPDS card 32-0533) and with the values of $a=10.1 \AA$ and $c=$ $7.38 \AA$ reported for the lead bromide phosphate (JCPDS card 06-0365).

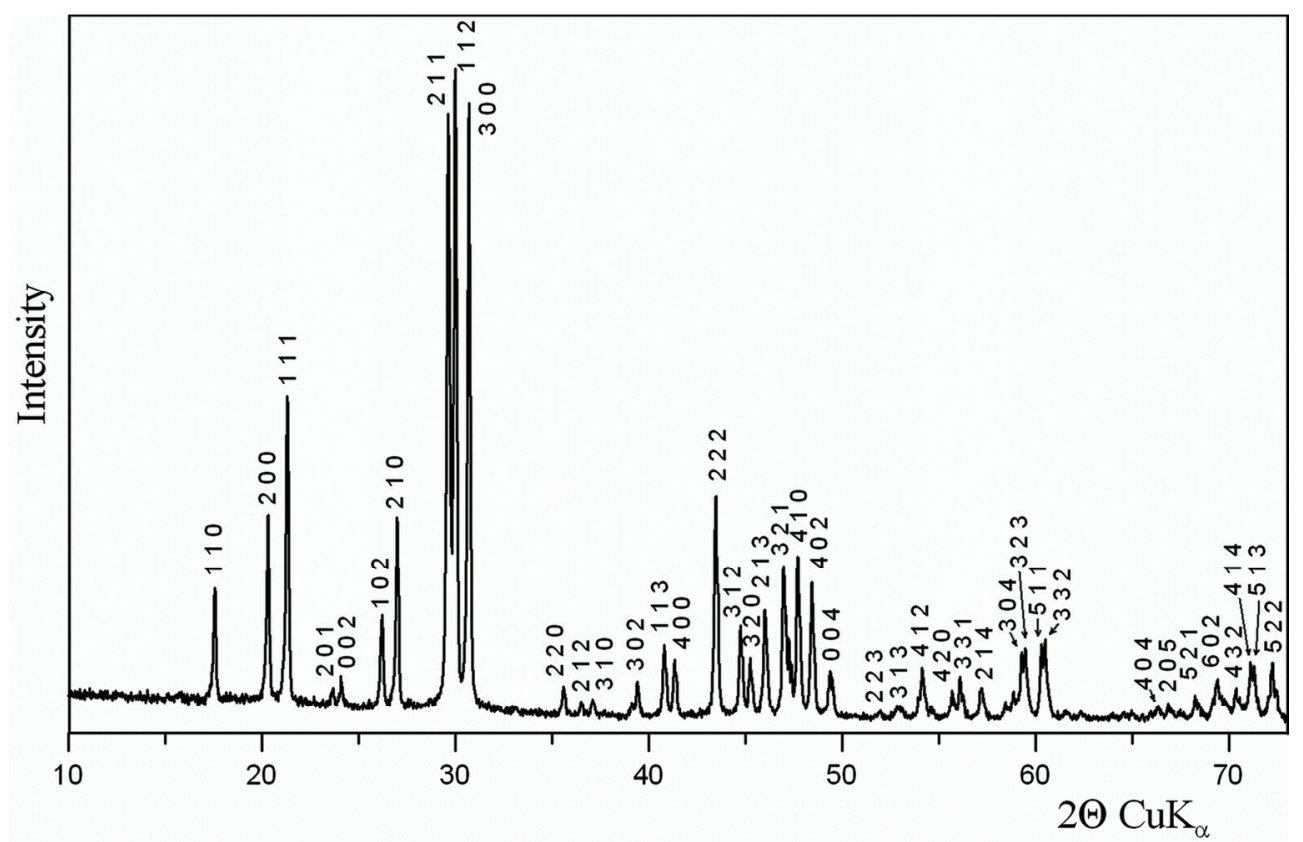

Fig. 1. XRD pattern of synthetic brompyromorphite. 


\subsection{Mid-IR spectra}

Mid-infrared spectra of synthetic brompyromorphite show characteristic bands originating from $\mathrm{P}-\mathrm{O}$ or $\mathrm{O}-\mathrm{P}-\mathrm{O}$ vibrations present in $\left[\mathrm{PO}_{4}\right]$ tetrahedra (Fig. 2). These are the bands due to the symmetric stretching vibration $v_{1}\left(922 \mathrm{~cm}^{-1}\right)$ and the $v_{3}$ asymmetric stretching modes $\left(1038,988,966 \mathrm{~cm}^{-1}\right)$ as well as bands originating from the asymmetric vibrations $v_{4}\left(575,542 \mathrm{~cm}^{-1}\right)$ and $v_{2}$ bending symmetric vibrations $\left(438 \mathrm{~cm}^{-1}\right)$ occurring within these tetrahedra. The number of bands due to $\left(\mathrm{PO}_{4}\right)^{3-}$ tetrahedra vibrations indicates a lowering of their symmetry from the $\mathrm{T}_{d}$ point group to the $\mathrm{C}_{2 v}$ group (Nakamoto et al. 1969).

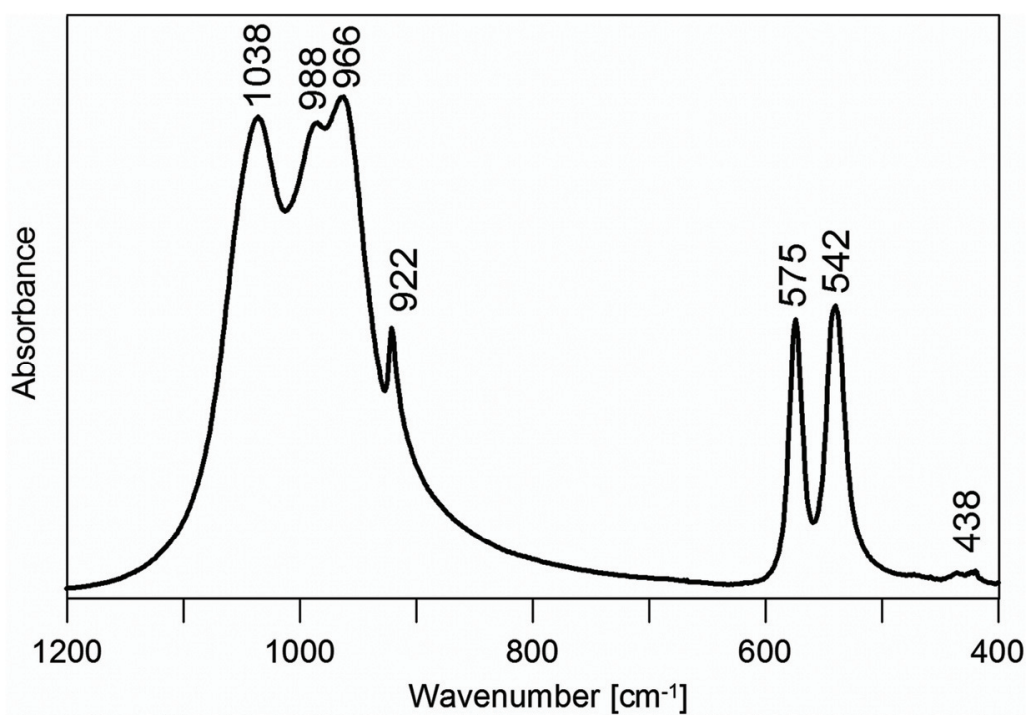

Fig. 2. Mid-IR absorption spectrum of synthetic brompyromorphite.

\subsection{Scanning electron microscopy (SEM)}

The SEM observations indicate that the precipitate is composed mainly of 1-2 $\mu \mathrm{m}$ grains. Among these grains, idiomorphic crystals in the form of a hexagonal prism and pyramid reach lengths of 5-10 $\mu$ m (Fig. 3). The surface of the grains is smooth. The crystals are composed of $\mathrm{Pb}, \mathrm{P}, \mathrm{O}$ and $\mathrm{Br}$ as determined by EDS. Neither the formation of others phases nor changes in crystal size or morphology were detected after 4 months. 

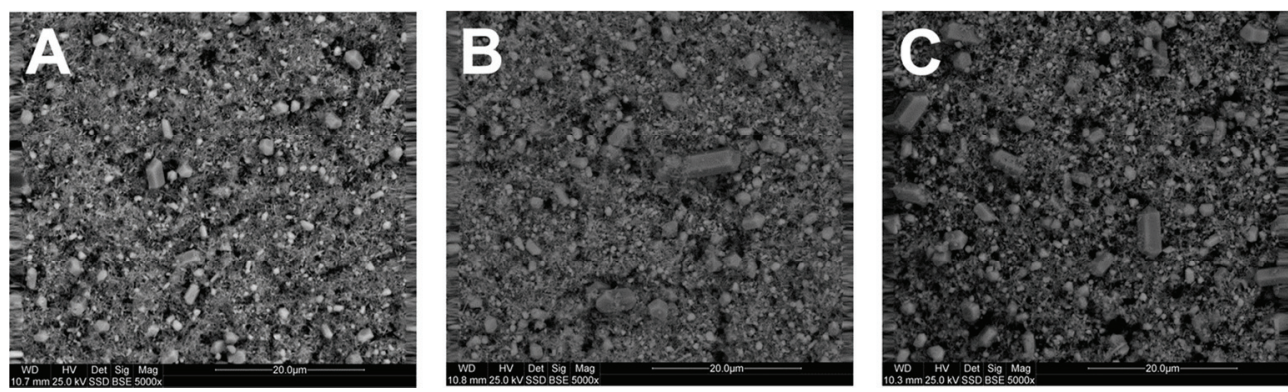

Fig. 3. Scanning electron microscope (SEM) image of synthetic brompyromorphite after 2 hours (A), 21 hours (B) and 28 days (C).

\subsection{Dissolution experiments}

In the dissolution experiments, most of the reaction occurred within the first week with dissolution rates, as indicated by the increase in lead concentration, declining with time. An example of the evolution of the solution composition over time is shown in Figure 4. The bromide analogue of pyromorphite dissolved stoichiometrically. The molar ratio of ions of $\mathrm{Pb}$ and $\mathrm{PO}_{4}$ in the aqueous solution was approximately 5:3 in accordance with the chemical formula $\mathrm{Pb}_{5}\left(\mathrm{PO}_{4}\right)_{3} \mathrm{Br}$. This indicates that the dissolution is congruent.

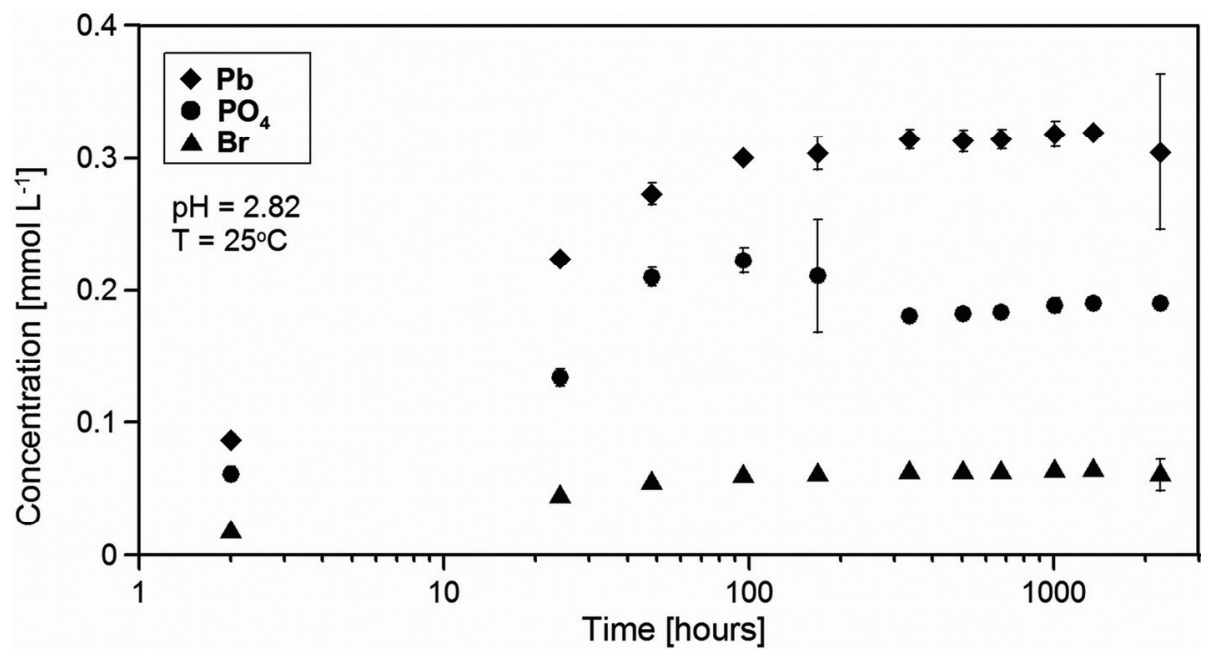

Fig. 4. Concentrations of $\mathrm{Pb}, \mathrm{PO}_{4}$, and $\mathrm{Br}$ in the dissolution experiment with initial $\mathrm{pH}$ of 2.60 (equilibrium $\mathrm{pH} 2.82$ ) and temperature $25^{\circ} \mathrm{C}$.

The brompyromorphite was considered to be in equilibrium with the solution when the compositions of two consecutive samples of the reaction solution were equal within error. At the initial $\mathrm{pH}$ values of 2.0 and 3.2, equilibrium was attained in 2 months whereas, for the initial $\mathrm{pH}$ of 2.6, equilibrium was reached after 14 days. The drift of $\mathrm{pH}$ was small $( \pm 0.1$ 
$\mathrm{pH}$ units) and speciation calculations on the equilibrium solutions indicate the formation of $\mathrm{H}_{2} \mathrm{PO}_{4}^{-}$and $\mathrm{HPO}_{4}{ }^{2-}$ ions from orthophosphate $\mathrm{PO}_{4}{ }^{3-}$ released to the solution from dissolving $\mathrm{Pb}_{5}\left(\mathrm{PO}_{4}\right)_{3} \mathrm{Br}$. The initial $\mathrm{pH}$ values of 2.0, 2.6 and 3.2 increased slightly to 2.12, 2.82 and 3.46 , respectively, as equilibrium was attained.

The ion activity product (IAP) for the dissolution reaction of brompyromorphite

$$
\mathrm{Pb}_{5}\left(\mathrm{PO}_{4}\right)_{3} \mathrm{Br} \Leftrightarrow 5 \mathrm{~Pb}^{2+}+3 \mathrm{PO}_{4}{ }^{3-}+\mathrm{Br}^{-}
$$

can be written as

$$
\log \mathrm{IAP}=5 \log \left\{\mathrm{Pb}^{2+}\right\}+3 \log \left\{\mathrm{PO}_{4}^{3-}\right\}+\left\{\mathrm{Br}^{-}\right\}
$$

where brackets denote activities. At equilibrium, the IAP is equal to the solubility product, $\mathrm{K}_{\mathrm{sp}}$. On the basis of measured concentrations and $\mathrm{pH}$ at equilibrium, the activities of $\mathrm{Pb}^{2+}$, $\mathrm{PO}_{4}{ }^{3-}$ and $\mathrm{Br}^{-}$were calculated with the aid of computer program PHREEQC. Based on the calculated activities, the log IAP was calculated using Eq. (2). The results of these calculations are presented in Table 1 . Since $\mathrm{K}_{\mathrm{sp}}$ is independent of $\mathrm{pH}$, the average equilibrium $\log$ IAP from the three $\mathrm{pH}$ experiments, represents the $\log \mathrm{K}_{\mathrm{sp}}$ at $25^{\circ} \mathrm{C}$ and equals $-77.38 \pm 0.70$. This value agrees well with the $\log \mathrm{K}_{\mathrm{sp}}=-78.1 \pm 0.1$ reported by Nriagu (1973).

TABLE 1

Calculated equilibrium activities

\begin{tabular}{lllllll}
\hline Sample & Temperature $\left[{ }^{\circ} \mathrm{C}\right]$ & $\mathrm{pH}$ & $\log \left\{\mathrm{Pb}^{2+}\right\}$ & $\log \left\{\mathrm{PO}_{4}{ }^{3-}\right\}$ & $\log \left\{\mathrm{Br}^{-}\right\}$ & $\log \mathrm{IAP}$ \\
\hline BrPY-2.0 & 25 & 2.12 & -3.331 & -18.770 & -3.611 & $-76.58 \pm 0.84$ \\
BrPY-2.6 & 25 & 2.82 & -3.992 & -17.816 & -4.289 & $-77.70 \pm 0.38$ \\
BrPY-3.2 & 25 & 3.46 & -4.453 & -16.952 & -4.743 & $-77.86 \pm 0.14$ \\
\hline
\end{tabular}

Based on the solubility product determined for brompyromorphite (BrPY) in the experiments, the Gibbs free energy of formation $\Delta \mathrm{G}_{\mathrm{f}}^{\circ}(\mathrm{BrPY})$ is calculated. The Gibbs free energy $\Delta \mathrm{G}_{\mathrm{r}}^{\circ}$ of dissolution reaction (1) expressed by the equation

$$
\Delta \mathrm{G}_{\mathrm{r}}^{\circ}=5 \Delta \mathrm{G}_{\mathrm{f}}^{\circ}\left(\mathrm{Pb}^{2+}\right)+3 \Delta \mathrm{G}_{\mathrm{f}}^{\circ}\left(\mathrm{PO}_{4}{ }^{3-}\right)+\Delta \mathrm{G}_{\mathrm{f}}^{\circ}\left(\mathrm{Br}^{-}\right)-\Delta \mathrm{G}_{\mathrm{f}}^{\circ}(\mathrm{BrPY})
$$

is, at equilibrium, related to the solubility product $\mathrm{K}_{\mathrm{sp}}$ as follows:

$$
\Delta \mathrm{G}_{\mathrm{r}}^{\circ}=-\mathrm{RT} \ln \mathrm{K}_{\mathrm{sp}}
$$

where $\mathrm{R}$ is the gas constant $\left(8.314472 \mathrm{~J} \mathrm{~mol}^{-1} \mathrm{~K}^{-1}\right)$ and $\mathrm{T}$ is the temperature $(298.15 \mathrm{~K})$. This gives a value for $\Delta \mathrm{G}_{\mathrm{r}}^{\circ}$ of $441.7 \pm 4.3 \mathrm{~kJ} \mathrm{~mol}^{-1}$. Calculation of the Gibbs free energy of the formation of brompyromorphite is enabled by equation 3 as follows:

$$
\Delta \mathrm{G}_{\mathrm{f}}^{\circ}(\mathrm{BrPY})=5 \Delta \mathrm{G}_{\mathrm{f}}^{\circ}\left(\mathrm{Pb}^{2+}\right)+3 \Delta \mathrm{G}_{\mathrm{f}}^{\circ}\left(\mathrm{PO}_{4}{ }^{3-}\right)+\Delta \mathrm{G}_{\mathrm{f}}^{\circ}\left(\mathrm{Br}^{-}\right)+\mathrm{RT} \ln K_{\mathrm{sp}}
$$

Based on available values of $\Delta \mathrm{G}_{\mathrm{f}}^{\circ}\left(\mathrm{Pb}^{2+}\right)=-24.40, \Delta \mathrm{G}_{\mathrm{f}}^{\circ}\left(\mathrm{PO}_{4}{ }^{3-}\right)=-1019.00$ and $\Delta \mathrm{G}_{\mathrm{f}}^{\circ}\left(\mathrm{Br}^{-}\right)=-104.01 \mathrm{~kJ} \mathrm{~mol}^{-1}$ from Robie et al. (1978) and the value of $\mathrm{K}_{\mathrm{sp}}=-77.38 \pm 0.70$ 
experimentally determined above, the Gibbs free energy of formation of BrPY may be calculated as $\Delta \mathrm{G}_{\mathrm{f}}^{\circ}(\mathrm{BrPY})=-3724.7 \pm 4.3 \mathrm{~kJ} \mathrm{~mol}^{-1}$. This value corresponds very well with the value of $3731.6 \mathrm{~kJ} \mathrm{~mol}^{-1}$ calculated by Nriagu (1973).

\section{Conclusions}

Experiments conducted by Nriagu (1973) indicated that in dilute phosphate solutions, $\mathrm{Pb}$ halides are rapidly converted to pyromorphites and/or pyromorphite solid solutions. Therefore, pyromorphites and brompyromorphites are believed to be the possible end products of $\mathrm{Pb}$ released to the environment. Because bromide is less abundant than chloride, the bromide analogue of pyromorphite will readily transform into pyromorhite. This is possible because pyromorhite is less soluble $\left(\log \mathrm{K}_{\mathrm{SP}}=-79.6\right.$; Flis et al. 2011) than the bromide analogue of pyromorphite $\left(\log \mathrm{K}_{\mathrm{SP}}=-77.38\right.$; this study).

Acknowledgements. We thank Adam Gaweł and Włodzimierz Mozgawa (AGH) for help with analyses. The research was financed by the AGH University of Science and Technology statutory grant.

\section{References}

Allison, J.D., Brown, D.S., \& Novo-Gradac, K.J. (1991). MINTEQA2/PRODEFA2, a geochemical assessment model for environmental systems: version 3.0 user's manual, EPA/600/3-91/021, Athens, GA: US Environmental Protection Agency, Environmental Research Laboratory.

Cotter-Howells, J. (1996). Lead phosphate formation in soils. Environmental Pollution, 93(1), 9-16. DOI: 10.1016/0269-7491(96)00020-6.

Figuła, A., \& Bajda, T. (2010). Formation of brom-pyromorphite as the effect of lead and phosphates sorption on surfactant-modified smectite. IMA2010: 20th general meeting of the International Mineralogical Association, 21-27 August 2010. Budapest, Hungary. Acta Mineralogica-Petrographica, Abstract Series, 6, 399.

Flis, J., Manecki, M., \& Bajda, T. (2011). Solubility of pyromorphite $\mathrm{Pb}_{5}\left(\mathrm{PO}_{4}\right)_{3} \mathrm{Cl}-$ mimeite $\mathrm{Pb}_{5}\left(\mathrm{AsO}_{4}\right)_{3} \mathrm{Cl}$ solid solution series. Geochimica et Cosmochimica Acta, 75(7), 1858-1868. DOI: 10.1016/j.gca.2011.01.021.

Krik, G., Scheckel, K.G., \& Ryan, J.A. (2002). Effects of Aging and pH on Dissolution Kinetics and Stability of Chloropyromorphite. Environmental Science and Technology, 36(10), 2198-2204. DOI: 10.1021/es015803g.

Lenoble, V., Deluchat, V., Serpaud, B., \& Bollinger, J.C. (2003). Arsenite oxidation and arsenate determination by the molybdene blue method. Talanta, 61(3), 267-276. DOI: 10.1016/S0039-9140(03)00274-1.

Nakamoto, A., Urasima, Y., Sugiura, S., Nakano, H., Yachi, T., \& Tadokoro, K. (1969). Pyromorphite-mimetite minerals from the Otaru-Matsukura barite mine in Hokkaido, Japan. Mineralogical Journal, 6(1-2), 85-101.

Nriagu, J.O. (1973). Lead orthophosphates. III: Stabilities of fluorpyromorphite and bromopyromorphite. Geochimica et Cosmochimica Acta, 37(7), 1735-1743. DOI: 10.1016/0016-7037(73)90159-2.

Pan, Y., \& Fleet M.E. (2002). Compositions of the Apatite-Group Minerals: Substitution Mechanisms and Controlling Factors. In M.J. Kohn, J. Rakovan \& J.M. Hughes (Eds.), Phosphates: geochemical, geobiological, and materials importance (pp. 13-49). Washington, D.C.: Mineralogical Society of America.

Pasero, M., Kampf, A.R., Ferraris, C., Pekov, I.V., Rakovan, J., \& White, T.J. (2010). Nomenclature of the apatite supergroup minerals. European Journal of Mineralogy, 22, 163-179.

Robie, R.A., Hemingway, B.S., \& Fisher, J.R. (1978). Thermodynamic Properties of Minerals and Related Substances at $298.15 \mathrm{~K}$ and 1 Bar (10 Pascals) Pressure and at Higher Temperatures, U.S. Geological Survey Bulletin 1452, Washington.

Shevade, A.V., Erickson, L., Pierzynski, G., \& Jiang, S. (2001). Formation and stability of substituted pyromorphites: A molecular modeling study. Journal of Hazardous Substance Research, 3(2), 1-12. 